\title{
The use of first language scaffolding to teach English as a foreign language to pre-school children during dramatic play in West Sumatera, Indonesia
}

\author{
Dewi Mulia
}

\begin{abstract}
The Indonesian community generally perceives that English language teaching should require phonology, vocabulary, grammar, discourse, and pragmatics. As a result, this often demands that pre-school teachers use English all the time. Code switching between English, Indonesian, and Minang - the local language of the region - is perceived negatively, and teachers are often criticized for using a multilingual approach that is "part snake and part eel" [sakarek ula sakarek baluik]. This refers to a negative perception of mixing languages in educational settings. In fact, code switching between Minang (first language), Indonesian (second language), and English (foreign language) is the norm of language use in this part of Indonesia. However, in this community, there is a lack of respect for pre-school teachers' professionalism as well as scepticism towards the effectiveness of a multilingual teaching approach, which is used widely at the pre-school level. Vygotsky [14], the Russian psychologist, presents a different perspective on this phenomenon, noting that children learn languages by playing. Their first language can be the main tool to help them understand new words and utterances in context. By using code switching, teachers help pre-school children to link their prior knowledge and experience to the new forms of expression that enable them to derive the meaning of new words from the social context of language use. For this reason, scaffolding techniques should be used by pre-school teachers, particularly in ways which support children's cognitive development in constructing new meanings based on their first language experience. This paper, based on a research studyin-progress at Deakin University, Melbourne, Australia, explores patterns of interaction between pre-school teachers and their students as teachers scaffold the development of EFL through dramatic play in West Sumatera, Indonesia. This interaction is systemic in nature and demonstrates consistent patterns of language use. The data described here is derived from a collaborative Action Research project with pre-school teachers in this community. The results are presented in the form of a narrative inquiry. These results challenge local perceptions of teachers' effectiveness in language education. Children, who have been taught English language through scaffolding, demonstrate physical, social, and cognitive development as a result of learning in and through playing in a multilingual context. This shows the positive role of code switching in EFL teaching at pre-school level in West Sumatera, and suggests a need to challenge existing community perceptions, thereby prompting a more serious consideration of this approach to EFL teaching in complex multilingual learning contexts.
\end{abstract}

This is an Open Access article distributed under the terms of the Creative Commons Attribution License 4.0, which permits unrestricted use, distribution, and reproduction in any medium, provided the original work is properly cited. 


\section{Theoretical framework}

A number of scholars perceive that English teaching requires the use of English in delivering English instruction; this is important to foster the acquisition of the targeted language. Krasen [11] believed that comprehensible exposure to targeted language was more effective in developing language acquisition. Philipson [14] highlighted that using either the first or second language in EFL mediated learning led to learning problems that slowed language-learning development. For that reason, it was argued that English teachers should speak like English natives. Apart from the need for exposure to native English speakers, it was considered that the use of switching language in teaching EFL would reduce the quality of output ([10] and [14]). The same perception is also felt in multilingual communities. In West Sumatera, Indonesia, for example, the community shows a lack of respect for the use of language switching, either for the combination of first language-second language or for first language-foreign language usage. At school, both parents and school management believe that the teaching of English should be undertaken by teachers who only use English in class. But the problem is that teachers find it difficult to use only English when teaching. The perception of a monolingual approach to teaching EFL is continuously debated by researchers, teachers, and by the community.

However, a number of studies argue against the perception of a monolingual approach, that is, the use of the targeted language only in multilingual situations. Atkinson [1] argued that the use of first language reinforces the meaning of words and expressions, filling gaps in meaning between native language and the targeted language. Auerbach [2] reported that the use of a first language in situations, such as giving instructions, explaining language errors, and addressing contextual meaning of words, brings a positive result. The use of first or second languages in teaching EFL at an early age is essential for several reasons. First, either the first or second language plays a critical role as a medium of instruction. And they can be switched when necessary. Second, the use of first language helps children relax and creates positive learning situations. Teachers may use the first language to explain complicated tasks, new words and expressions to the children. Third, the use of code switching allows children to express freely their thoughts and feelings, in order to develop their communication skills. In situations when children's capacities in mastering English words and expressions are still limited, code switching is essential to help them remain vocal in class, instead of being silent, because they lack vocabulary and word expressions ([1, 6, 7,9] and [15]). Although current researchers agree that first language is important in teaching EFL, few studies investigate the use of first language and second languages in teaching EFL in early childhood settings. This is why the following discussion will rely on the role of first and second languages in learning a foreign language at an early age, when children live in a multilingual environment.

\section{The role of first language in EFL learning in early childhood settings}

As it is linked to the discussion of early childhood settings, language is a crucial source in children's cognitive development. Language develops human thought. Thus language is a tool to transmit information and ideas. It is common for teachers within a classroom to translate the mother tongue or second language into English words; however, little attention is paid to understanding the use of language as a 'mediative role' in learning a foreign language [17].

Learning a new word in a foreign language is not just translating the word of the targeted language, but more rigorously mastering a concept. Concept formation is an interactive process of the individual's concept with the social world. The concept formation in a child's thought is not innate. A child is given meaning through the help of adults. Vygotsky argues, 'he only follows the practice already established by adults' [17]. Analogously, I argue that learning a foreign language is the process of establishing interactive language use in the social world. The use of language by adults thus links the external social world to internal, individual mental processes. 
For that reason, the use of children's prior language, either the mother tongue or second language is a tool for learning new foreign words. The new word is confronted by existing language to a verbal thought. Vygotsky [17] confirms that "a foreign word is not immediately related to its object, but through the meanings already established in the native language" (p. 197). Therefore native language is a tool to develop children's internalized knowledge and forms of abstract thought:

Success in learning a foreign language is contingent on a certain degree of maturity in the native language. The child can transfer to the new language the system of meanings he already possesses in his own. The reverse is also true - a foreign language facilitates mastering the higher forms of the native language (p. 196).

There is a mutual relationship between first language and foreign language. They facilitate each other in making meaning of words and expression. Moreover, according to Cook [6], "The first language can be a useful element in creating authentic L2 uses rather than something to be shunned at all costs" (p. 185).

Hence I argue that collaboratively working with a pre-school teacher in Action Research deepens our understanding of the mutual relationship between first language and foreign language. This project allows us (critically and comprehensively) to look at the process of how a teacher scaffolds the EFL development of pre-school children in presenting a foreign language through the use of first and second languages during dramatic play activities.

\section{Action Research design}

Action Research is the process of sharing knowledge, implementing, reflecting, and framing better outcomes, emerging from "self-reflective collective and self-study of practice" [12]. During last two years, I was engaged in West Sumatera, with a pre-school teacher in framing a better approach to teaching foreign language in pre-school settings. For this reason, participatory Action Research was my research method. Kemmis [12] describes three points that distinguish participatory Action Research from conventional research. They are "shared ownership of [the] research project, community-based analysis to social problems, and orientation towards community action."

Through these activities, Action Research creates conditions under which learning communities will become established, that is, communities of inquiry committed to learning about (and understanding) the problems and effects of action strategies, how they implement them, and improve these strategies in practice [12].

Mediation is a key concept in this Action Research project, in which teachers help children to engage in active interaction in a dramatic play by using physical tools and language. This activity leads to the social construction of meaning, in particular, in English as a foreign language.

To mediate children's meaning making in a foreign language in a relevant activity is often complex; for example, teachers are required to design imaginative classrooms, which encourages children to be actively engaged in play, and to design interventions of targeted English language use based on the theme of the school curriculum. To challenge this complexity, there is a need to do Action Research, and to focus and reflect on the mediation process itself. The questions which are explored in this research are consistent with the activity theory perspective of Vygotsky. It shows the role of language use in scaffolding children's making meaning of new words and phrases. As for Vygotsky [17], a learning activity in a classroom is situated learning, which is facilitated and organized by a teacher with an ultimate goal: to reach "higher mental function".

\section{Project setting}

The research was conducted in Padang, the capital of West Sumatera, located on the West Coast of Sumatera, which has a population of over 833,000 people. Most of the inhabitants are Muslim. According to the Department of Cultural and Tourism Affairs, West Sumaterans live in a multilingual 
context. They speak Minang Kabau as a first language for daily use, and Indonesian, the official language in Indonesia, as a second language. Padang was chosen for several reasons; Padang is the largest city in West Sumatera, and the inhabitants speak a standard first language, which is Minang Kabau.

In West Sumatera, the first language is Minang Kabau. However, there are numerous different dialects in the regions. To be specific, the two main dialects are coastal and highland. The coastal region includes the dialect of Padang and Pesisir Selatan. The highland region uses three different dialects. The first is Luhak Agam, which covers Bukittinggi, Maninjau, and Lubuk Basung. The second dialect is Luhak Tanah Data, which covers Batusangka, Padang Panjang, Singkarak, and Kayutanam. The third is Luhak 50 Kota, which covers Payakumbuh. It is interesting to note that the dialect of Padang is used as the standard first language in West Sumatera, and it is used for communicating with other first language speakers.

West Sumateran peoples have been familiar with foreign language learning for generations. Thus learning a foreign language is not a new phenomenon. I learnt foreign language from my grandfather, who spoke Dutch and Japanese, as a result of foreign colonization in West Sumatera. In fact, there are lots of borrowed words from various foreign languages such as Dutch and Arabic. Besides the effect of colonization, West Sumatera people use foreign language for religious purposes. The Department of Cultural and Tourism Affairs of West Sumatera reported that the written language of Minang Kabau was originally derived from Arabic. Besides using their mother tongue and acquiring the official language Bahasa, young children in West Sumatera start learning Arabic in their early years. Interestingly in most pre-schools, children memorize small parts of noble Q'uran, the holy book of Muslim, which is written in Arabic. From an early age, I studied Arabic by memorizing new words as well as long sentences.

\section{Data collection}

With my co-researcher I video recorded dramatic class activities to both capture the interactions between teachers and children and between children. Two cameras were placed in two corners of the classroom; we also used four voice recorders aimed at clearly capturing the voices of children who were moving around. Both cameras were placed at a distance from the children. This is why, on occasion, the voices were not optimally captured. Since I observed physical movements, body language, and facial expressions, I sometimes took the camera closer to children where they played. Considering comfort and convenience, the camera was taken closer after the third week of data collection. I used a combination for data collection including dialogue, observation, field notes, and journal/diary.

Because Action Research is embedded in ongoing reflection throughout cyclical actions, I worked with my co-researcher to analyse the data from the outset of the research. The analysis of the previous class performance, both teacher and student performances, was used to determine the intentional / potential teaching approach design for future actions. For example, as we implemented the intervention at the first cycle, we watched the video, observed and discussed. The result of our discussions was documented in field notes. Once we had collected over a week's data, we analysed it in order to identify the problem found in teaching EFL at pre-school. Analysis enabled us to discuss, develop and design mediation during dramatic play. Data sources were audio recording, but also field notes, anecdotal notes from the teacher, and records from the teacher's portfolio. The entire process was either audio or video recorded, and this data was collected in order to look more closely at the interactions between teachers and children, as well as the teacher's scaffolding process that mediated EFL learning for students through dramatic play.

At the end of the data collection phase, I grouped the data into patterns for analysis. These patterns corresponded to the general research question. Since this is a cyclical process of data discussion and analysis, I presented the findings, which are fully responsive to the cyclical inquiry process, on the basis of plan-act, observe and review. Interestingly, new questions appeared in response to the learning situation. As Kemmis [12] stressed, "the process is likely to be more fluid, open and responsive". 
The discussion of data is presented in narratives as the unit of analysis. Vygotsky [17] argues that narrative analysis challenges researchers to deepen their understanding of contextual findings, which are associated with social context. Presenting a narrative analysis implies a dialogical collaboration between researcher and teacher in a cyclical process of data collection.

\section{Subjects}

The total number of pre-school children who participated in the project was ten. They were five to six years' old. Children spoke different languages both at home and school. They spoke their first language at home, Minang Kabau, to communicate with immediate family and peers. At school, they spoke both first and second languages. They usually spoke the former to communicate with their peers; however, to communicate with teachers, they sometimes switched to their second language. As previously mentioned, the second language of West Sumatera people is Bahasa Indonesian, a national language officially used in formal settings. One teacher participated as a partner in my collaborative Action Research. She had ten years' teaching experience, in particular in teaching EFL at pre-school.

\section{Phase one}

To understand how the shift between teaching and learning processes occurs during a cycle of Action Research, it is essential to discuss the current features of a pre-school classroom prior to mediation/intervention. I believe that learning takes place in a situation which determines individual action and interpersonal interaction. As Vygotsky [17] suggests, teachers should create a learning situation, which optimally supports children to use language, remains in touch with real-world situations, and fosters interaction and collaboration among peers.

In this project, the classroom environment was designed within a socio-cultural context. For example, classroom walls were decorated to create a beach setting. The beach theme was chosen because Padang is located on the coast. This was confirmed by Ms. Deswita, my co-researcher, who said "the theme of [the] beach on the wall aimed at getting children to know their surroundings, which was Padang beach". The banner with monkeys and "orang-utan", birds, and other specific animals from West Sumatera were used to introduce native animals to children. There were posters of specific fruits and vegetables from Indonesia as well. Ms. Deswita observed there were some posters of Alqur'an words and sentences to represent the religious background of students. Those contextual features of decoration were considered as an effective approach to allowing children to know the world around them.

Besides classroom decoration, furniture arrangement was a critical component in order to successfully deliver learning [16]. At that point, I observed classroom furniture with great interest. Children were provided with chairs and desks, but there were no rugs on the floor in the classroom. In this four by five metre classroom, there were two rows of chairs, consisting of five to six chairs each. A whiteboard stood in front of the desks. A teacher's desk was placed between children's desks and the whiteboard. Ms. Deswita noted that children learned at their desks, and played there too. During play time, children were allowed to place play materials on their desks. I did not share the teacher's view, arguing that using desks as play areas was the best way to monitor children's play activities and materials. I asserted that using a rug would allow children to relax and feel more at home. Moreover, considering using a coloured rug for more attractive and creative reasons could serve imaginative learning situations as well. A play area with a rug does not require a big space; however, it can better serve children's active and interactive play. As Vekelich and Christie [16] claim, "bigger is not always better" (p. 17). Well organized play areas encourage children to engage in positive, interactive activity. In the research project, my co-researcher and I not only worked together to critically look at the classroom arrangement and decoration, in order to serve contextual, imaginative, and creative learning situations, but we also discussed the use of language in class activities. 
When I suggested investigating teaching and learning a foreign language using Action Research, the teacher was happy, since she needed ideas and information on how to teach EFL at pre-school. She revealed that she found the situation overwhelming when she used a combination of first, second and English languages. School management and parents expected her to use only English in English classes. As a result, only Ms. Deswita taught EFL at the school. She explained the main reason why she used first language in delivering English words and phrases was because she was not totally fluent in English. Other teachers expressed their lack of confidence in teaching EFL. They perceived inadequate English fluency and lack of teacher training as the main reasons for avoiding English words and phrases in class activities. In addition to teacher and school management perceptions, the community of West Sumatera was not in favour of code switching. They expected people to use exclusively their first language in daily life communication. As an academic researcher, these complex situations should be challenged through dialogic inquiry. This is a process of seeking alternatives to teaching practice through argumentative dialogue between the researcher and pre-school teacher. For Bakhtin [4], an interpersonal dialogue helps examine the issues and generates alternative solutions responsive to the context in reflective and critical ways.

In this context, it was important to see the gaps in practice and knowledge prior to conducting the cyclic Action Research project. My discussion with the teacher led us to reflect critically on the learning environment, to think about the children's routine at school, the programme the pre-school offered, and which learning and playing opportunities were provided at school. Most importantly, we carefully investigated the use of language over play activities.

\section{Mediation process}

My participation in this project not only allowed a productive discussion with my research partner on generating knowledge in enhancing practicalities and facing epistemological challenges of teaching EFL in early age education settings; but it also facilitated a deeper understanding of complex educational settings in order to improve EFL learning activities. Therefore, essentially, I not only intended to help the teachers bring about change in perceptions toward the use of first language in teaching EFL, but also assisted with their teaching practice, in particular, the use of English words and phrases through dramatic play activity in the classroom. I argued that the focus of teaching and learning EFL from an early age should mainly develop vocabulary and simple utterances of English, instead of grammar, pronunciation, writing and reading. At that point, I went through two cycles of Action Research with the teacher; we designed dramatic play activity, intervened and mediated, observed video recordings, reflected on the intervention, and then modified the initial dramatic play session.

Before designing dramatic play activity, I worked with the co-researcher to identify past and current issues linked to EFL teaching in pre-school settings, and potential improved practices. Those initial reflections generated a substantial part of the data, which informed a potential design for initial intervention. We finally concluded that dramatic play activity was critical in promoting children's language development.

At the initial implementation of dramatic play, we found that the teacher used translation techniques, instead of helping children make meaning through positive social interaction. The following dialogue informed us on the reflectivity of teaching and learning EFL words and phrases:

Teacher: mmm very good, stand up apa nak, berdiri

[00:04:00.19] Okee, Lagii...sit down please

[00:04:15.13] Keyza: sit down please

Teacher: oke, haa, misalnya anak ribut, apa dibilang, kalau, supaya ndk ribut gimana [00:04:14.29] Putri: hush!

Teacher: silent please, gimana nak? 
[00:04:19.29] Keyza: silent please

Teacher: okee, very good, tepuk tangannya.

We discussed the video recording of the initial intervention above, which illustrated the use of translation to help children make meaning of words and phrases. The teacher asked a question in order to find the first language word or expressions in English. Obviously, children tended to find the concept of new words in their own language. However, from my point of view, children should be challenged to understand the concept through social interaction. When they heard a new sentence, for example, "sit down please", the teacher should have created a situation which encouraged children to engage in modelling and playful interaction.

\section{Reflection}

As a part of our initial reflection, the teacher and I agreed she should take part in a "school" scenario and pretend to be "someone". I added that the transformation from teacher to "student" brought more positive results than the initial intervention. The teacher replied she had never experienced acting out in children's dramatic play. This was definitely challenging for her. However, she eventually agreed to modify her role in dramatic play. Besides the transformation of the role, we also agreed that the teacher should use active verbal language, either first, second, or foreign language, along the lines of dramatic play activity. We argued that using first language in delivering EFL words and phrases in turn avoided translation. We believed these two modifications of dramatic play activity would scaffold children's making meaning of EFL and they would use it in a spontaneous way. To revisit the process in a critical way was an important session, to improve the teaching and learning process along the cyclic procedure of the project.

During the second intervention, my co-researcher applied the modified planning. She initially explained to the children that she would engage in the scenario. She started the dramatic play activity by picking up one of the children's seats and said:

"Saya mau jadi student, siapa yang ingin jadi student?" [I want to be a student, who will be a student?]

All eyes turned toward her. Children seemed happy when they saw their teacher's changing role. Besides visibly excited faces, children seemed to be more active, both verbally and non-verbally. When the teacher acted out like a child in the class, and used her verbal language, the children carefully examined her acts, in particular, the use of foreign language. To justify the situation, we argued that the transformation of the role allowed the teacher to access children's pretend play. In other words, the development of children's speech should be supported by auditory and visual information. The former (auditory) was verbal language, which could be a combination of languages, while the latter (visual) was represented in non-verbal language, such as body language, acts, and body movement.

Then we discussed our experience and reflected on our findings. We considered that four strategies could be implemented at our next meeting. First, we would provide advanced modelling by engaging in socio-dramatic play ourselves and pretending to be actors in the scenario. This scenario would aim at demonstrating to the children how to act in character. Second, we considered that we needed to mix languages in order to help the children understand symbols and contextual use of words and expressions. Third, in order to facilitate the children's participation in the imaginary situation, we would provide more rigorous material. In order to see progress, we thought we would continue to use the same scenario of "being a teacher".

\section{Phase two}

At our second meeting, we felt the children were beginning to develop their imagination, instead of repeating their teacher's sentences. My co-researcher pretended to be a student and sat down in one 
of the children's seats. Angie, the girl who was playing the teacher, asked us our names. I raised my hand and said, "My name is Asti." She was demonstrating how to say one's name. In order to create an environment to learn new words through context use, which is the most natural way, we often combined the children's first and second languages and English, and my research partner avoided using the sentence, "We are studying English now."

In addition, we used body language, gestures and facial expressions to help the children internalize the meaning of the words and simple expressions we targeted. For example, the children did not at first know the meaning of the simple direction, "Stand up please." However, they could make meaning of this concept when the teacher demonstrated by standing up from her chair. The simple instruction, "Clap your hands" was shown with the use of body language.

In the teaching and learning process, the context of a word is a key factor in helping children to understand its targeted meaning, as well as the process of mediation of making meaning. The word meaning may go wrong if the process of meaning making does not meet the situational requirement, because it fails to provide the exact information needed or the targeted new word. Vygotsky stated that information acquired from context needs native language to mediate objects and targeted meaning. Word meaning develops as context changes, which is determined by language users as agents of the community. Therefore, to consider making meaning of new words, we should be concerned with the socio-cultural and historical context. Vygotsky [17] stated that "word meaning is more dynamic rather than static formations" (p. 217). In particular, I argue that the use of native language and second language, together with foreign language, can be used to link social understanding and the individual's concept formations.

As for the challenges my co-researcher found, I began to wonder how we could change the perception of teaching EFL from an early age. Teachers perceive that teaching EFL should cover grammar, phonology, reading, writing, and pronunciation. For example, I learned they introduced the way of pronouncing a letter of EFL. Written English also appeared in the posters of objects. The teacher explained that she had introduced children to written English along with vocabulary. She perceived that "fun" learning occurred through singing songs.

At the initial implementation of the intervention design, the theme of the pre-school was "school". This theme aimed at introducing children to the school environment. I worked with the teacher to set up dramatic play associated with this theme. More specifically, the goal in the EFL section was that children were expected to internalize the phrases related to school activities, such as greeting "good morning", "how are you?", "good bye". The objects associated with the school environment, such as teacher, students, classroom, toilet, books, pencil, pens were the target of initial EFL learning. At the initial phase of the activity, Ms. Deswita and I expected that children would be surprised to hear new words and sentences during dramatic play activity. This first intervention was then discussed. We sat together to look at the process of dramatic play activity and the response of children to the use of foreign words and phrases.

As proof of evidence, for example, I observed one of the children, "Alya", talking to himself while counting the floor levels of the house he had created with blocks. I did not see him speaking to his friends at that point. Interestingly, he was talking to himself using English words, saying "one, two, three...". Of course, this situation took place after several interventions from Ms. Deswita. Looking back at the previous intervention, initially, Ms. Deswita switched her language to EFL when she approached Alya while playing with the blocks. She said "Wow, you have a tall building!" Alya looked happy and he responded with a big smile. Ms. Deswita asked him in Indonesian language, "berapa tinggi gedungnya" (how many levels are there in your building), "ayo kita hitung" (let's count it). Alya spontaneously responded, "satu, dua, tiga". At the same time, Ms. Deswita counted, "one, two, three..." Amazingly, Alya spontaneously stopped counting in Indonesian and switched to English, "one, two, three...", together with Ms. Deswita. When he got stuck on a specific number (e.g. eleven), which perhaps he 
did not know, he looked at his teacher. His body language demonstrated that he needed her assistance. Ms. Deswita helped him by saying "eleven" and Alya then continued counting.

The process of moving from not knowing without assistance to knowing with assistance is called internalization within the ZPD concept [17]. Alya required assistance, especially in counting up to twenty. It was surprising then that Alya talked to himself, counting in English without any assistance and instruction. I observed that the process involved scaffolding and interaction with the teacher. In other words, individual thought is not isolated; however, Alya's self-talk in this project appeared after gradual intervention. For that reason, in the context of foreign language learning, the concept of self-talk is strongly related to social interactions, mediated by psychological and cultural tools ([3, 13], and [14]).

\section{Conclusion}

The overall cyclical process of mediation shows that the use of first language is essential in scaffolding children's making meaning of new words and expressions. On our first day, the researchers planned to have the children use their imagination in a short scenario, "being a teacher". We hoped that some of the children would volunteer. My co-researcher chose one of them, and asked her to stand in front of the class. She said, "Ini teacher Nikki" (This is teacher Nikki). This meant she was guiding the children in play activity by using two different languages: Indonesian and English. Then she outlined a classroom situation for the children and assisted by telling them what a teacher looked like. By scaffolding their play, she demonstrated to the children how to behave when teaching in a classroom. She used a combination of languages, the pre-existing language and English, in order to help them make meaning of objects and actions symbolically. Thus use of their first language and English as a foreign language during dramatic play helped these children make meaning of the concept in a natural way.

\section{References}

[1] D. Atkinson, The Mother tongue in the classroom: a neglected resource? ELT Journal, 41, 4 (1987), 241-7

[2] E. Auerbach, Re-examining English only in the ESL classroom, TESOL Quarterly, 27, 1 (1993), 9-32

[3] E. Bodrova \& D. Leong. Tools of the mind: the Vygotskian approach to early childhood education (2nd ed.). (Upper Saddle River, N.J.: Pearson/Merrill Prentice Hall, 2007)

[4] M.M. Bakhtin. The dialogic imagination (M. Holquist, Ed., C. Emerson \& M. Holquist Barrow, R., \& Woods, R.G. (1981)

[5] H.D. Brown, Principles of language learning and teaching, 4th edn. (New York: Pearson Education, 2000), ELT Journal, 41, 4, 214-47

[6] V.J. Cook, Going beyond the native speaker in language teaching, TESOL Quarterly, 33, 2 (1999), 185-209

[7] V.J. Cook, Using the first language in the classroom, The Canadian Modern Language Review/La Revue Canadienne des Languages Vivantes, 57, 3 (2001), 402-23

[8] M. Critchley, Bilingual support in English classes in Japan: A survey of student opinions of L1 use by foreign teachers, The Language Teacher, 23, 9 (1999), 10-13

[9] J. Harbord, The use of mother tongue in the classroom, ELT Journal, 46, 4 (1992), 350-55

[10] P. Hawks, Making distinctions: a discussion of the mother tongue in the foreign language classroom, Hwa Kang Journal of TEFL, 7 (2001), 47-55

[11] S.D. Krashen, The input hypothesis: issues and implications (London and New York: Longman, 1985)

[12] S. Kemmis and R. McTaggart. The Action Research planner (Deakin University Press, 1988) 
[13] A. Kozulin, Vygotsky's educational theory in cultural context (UK; New York: Cambridge University Press, 2003)

[14] R. Phillipson, Linguistic imperialism (Oxford: Oxford University Press, 1992)

[15] N. Storch, G. Wigglesworth, Is there a role for the use of L1 in an L2 setting? TESOL Quarterly, 37, 4 (2003), 760-9

[16] C. Vukelich and J. Christie, Building a foundation for preschool literacy: effective instruction for children's reading and writing development (USA, International Reading Assoc., 2009)

[17] L.S. Vygotsky, Thought and language (New York: Plenum Press, 1986) 